\title{
Cadaveric dissection by students-monitors in human anatomy discipline: experience report
}

\author{
MORAES, G. N. B. ${ }^{1}$, FALCÃO, J. G. B. ${ }^{1}$, SANDES, A. A. G. ${ }^{1}$, \\ RODRIGUES, B. R. ${ }^{1}$, NASCIMENTO, I. Y. M. ${ }^{1}$, SCHWINGEL, P. A. ${ }^{2}$ and \\ SILVA JÚNIOR, E. X. ${ }^{3 *}$
}

\begin{abstract}
${ }^{1}$ Human Anatomy Teaching and Research Laboratory - LABEPAH, Universidade de Pernambuco - UPE, BR 203, Km 02, s/n, CEP 56328-903, Petrolina, PE, Brazil

${ }^{2}$ Research Laboratory for Human Performance, Departament of Nutrition, Universidade de Pernambuco - UPE, BR 203, Km 02, s/n, CEP 56328-903, Petrolina, PE, Brazil

${ }^{3}$ Human Anatomy Teaching and Research Laboratory - LABEPAH, Departament of Physiotherapy, Universidade de Pernambuco - UPE, BR 203, Km 02, s/n, CEP 56328-903, Petrolina, PE, Brazil

*E-mail: edivaldo.junior@upe.br
\end{abstract}

\begin{abstract}
Introduction: Monitoring allows students the basic cycle of higher-level courses, principally, a deeper understanding of all content been living in class, in this case, the Human Anatomy classes. Through it the student develops various daily activities at the Human Anatomy Laboratory to that add up to the didactic and pedagogical activities required in this process, like the cadaveric dissection. Dissect derives from the Latin meaning to separate, cut, etymologically being equivalent to anatomy. The present study aimed to report the student-monitor experience the discipline of Human Anatomy in cadaveric dissection. Methods: The study is an experience report of a qualitative approach, with an exploratory descriptive analysis, whose objective was to describe, in the words of Physiotherapy course monitors, the importance in the dissection technique. For this, has been made the reading for each reporting for the identification of the central issues described by each monitor. Results: The reports were obtained in February 2014 soon after the end of the I Course of cadaveric dissection of Upper and Lower Limbs, sponsored by the Human Anatomy Laboratory of the University of Pernambuco, Petrolina, as a process of training to those student-monitors who had been selected for the period between 2014.1 and 2014.2 monitoring. Conclusion: It could be perceived that the cadaveric dissection was seen as a way to strengthen the humanization of future health professionals, which resulted in its ethical and social practice, and it has allowed an improvement in teacher-monitor-student relationship.
\end{abstract}

Keywords: dissection, human anatomy, anatomy teaching.

\section{Introduction}

It is known that the discipline of human anatomy awakens in students of health courses, the curiosity about the human body in a more comprehensive way, where direct contact with the corpse pieces instigates the quest for knowledge of organs and systems that compose. Thus it meant that human anatomy is a science which is part of the field of biological sciences, wherein studies of macro and microscopic form the human body and is essential to the training of professionals in the health area (GRAY and GOSS, 2012; DANGELO and FATTINI, 2007; PIAZZA and CHASSOT, 2012).

On this discipline, so complex and extensive in its information, monitoring provides to students the basic cycle of health courses, a better comprehension and understanding of the whole process experienced by them in the classroom (PAIXÃO, SANTOS and BARLETTA, 2010), as well as be a link between the professor and their, respective student (LEITE, SILVA and VAZ, 2005; NASCIMENTO and BARLETTA, 2011).

This practical is used in most institutions at the national level, which provides the addition of these student-monitors in the act of teaching (FRANCO, 1998). Monitoring allows the student a thorough learning of the course content, which is a pedagogical model in the teaching learning experience.
With this prevents, or may decrease, deficits in pedagogical practice in the training of university professors, especially health professors. (NASCIMENTO and BARLETTA, 2011). Some higher education institutions have already called this experience as the Initiation Teaching Higher Education.

In monitoring the student has contact, direct, with several experiences in higher education teaching, among them, the dissection of human corpses. The cadaveric dissection provides knowledge, teaching and learning of anatomical structures allows for corrections on wrong conceptions, contributes to the personal development of students and allows to know the topographic anatomical variations, mainly vascular, which is understood as normal, since the humans it isn't exactly identical to each other one (BABINSKI, SGROTT, LUZ et al., 2003; COLLIPAL and SILVA, 2011; TURNEY, 2007; PABST, 2002; MARTYN, BARRETT, TROTMAN et al., 2012). This experience lately, is has been increasingly scarcer by the lack of corpses unclaimed by their families because according to the 8501 law in November 1992, they should be intended only for universities and/or colleges that have medical schools, leaving aside those universities and colleges health courses that don't have medicine course (BRASIL, 1992). 
Dissect provides the student-monitor a unique experience in covering their knowledge of human anatomy, which may corroborate that was experienced in lectures and practical classes, with human anatomical models and the books themselves. So, it is important to spread experiences, like that of the students of Physiotherapy course at the University of Pernambuco (UPE), Petrolina, since in the literature there are few studies reporting this type of great value experience to the academic life students as well, glimpses a possibility, future, to contribute in changing the 8501 law and allow other universities and colleges, which have health courses can receive these bodies unclaimed by their families. Thus, the study aimed to report the experience in cadaveric dissection student-monitors the discipline of human anatomy of the Physiotherapy course at UPE, Petrolina.

\section{Methodology}

The monitors students of the Physiotherapy course at UPE, Petrolina, have attended the I Course of cadaveric dissection of Upper and Lower Limbs sponsored by Human Anatomy Laboratory of that university during the month of the period of February 2014 as a training process. Then, was asked these students an essay, in his own hand on his experience in his first contact with the corpse and your first contact with the cadaveric dissection.

The study is qualitative, through an experience report, with the aim to describe, in the words of the monitors, the importance in cadaveric dissection of technical in the course of Physiotherapy. For the interpretation of the data, an exploratory descriptive analysis was performed by reading each reporting to identify the central issues described by each student-monitor. The categories that emerged after the analysis were: The importance of practicing cadaveric dissection; Anxiety; Teaching-learning process; Proximity to reality; Professor- student interaction; Professional contribution; Shortage of human corpse to practice dissection; Ethical and humanistic approach.

Data collection has complied with the ethical principles set out in Resolution 466/2012 of the National Health Council and was approved by the Ethics Committee on Human Research from University of Pernambuco about registration 34051114.8.0000.5207. The students were informed that their personal data would be preserved, and that the information provided would not be used to identify them. All participants signed a Free and Informed Consent Term. In no time the participants have been coerced or induced to change their contents.

\section{Results and Discussion}

The human anatomy is a basic discipline for all students entering in health courses (SIQUEIRO NETO and FERREIRA, 2001; KRUSE, 2004), being the basis for understanding other fundamental disciplines such as Physiology, Pathology and Clinical (TAVANO, 2011). In it, students learn the shape and location of the human body structures, correlating them with their functions (BRAZ, 2009). For this knowledge goes ahead, several methodologies are applied, among them the practical of dissection human corpse (BRAZ, 2009; COSTA and FEIJÓS, 2009). The collected reports follow below demonstrating the importance of this activity for students of health courses and their sensations in the development of the activity.

\subsection{The importance of practicing cadaveric dissection}

A study in British universities has shown that the use of human corpse was the preferred method for students to reach a set course of medical objectives, the first being dissected and, secondly, the use of researches (KERBY, SHUKUR and SHALOUB, 2011). Such the importance given to the use of corpse in health courses at that author's work, was observed in the speech of monitors this importance attached by them the practical of human anatomy, being seen as a factor of encouragement for monitoring activity.

The dissection is an important activity for monitors of buman anatomy $[. .$.$] (Student-monitor 1)$.

[...] how important is the use of the corpse in practical classes in buman anatomy and neuroanatomy [...] (Student-monitor 2).

The first contact with the corpse was, however, a source of anxiety and curiosity, given the importance of knowledge to be gained from that experience [...] (Student-monitor $3)$.

The cadaveric dissection was a unique experience that brought us an unparalleled knowledge of Human Anatomy [...] (Student-monitor 4).

According Aversi-Ferreira, Nascimento, Vera et al. (2010), the dissection of corpses in human anatomy is an important tool for medical education, as a teaching methodology that encourages critical and investigative thinking, integrating basic education to clinical knowledge. Thus, the inclusion of cadaveric dissection practice is extremely positive for extended contact with discipline.

\subsection{Anxiety}

It is normal to find students anxieties for their first contact with corpse parts as a whole. Martyn, Barrett, Trotman et al. (2012) realized the impact of 16 medical school students anxiety in dissection heart and brain. These have owned distinct anxieties referred to the organs involved, reporting that they have felt thrilled to be removing the heart, and the same one to be related to the emotions; while some mentioned being weird dissect the brain, as the responsible body to characterize the human personality. This same anxiety for dissection, was noted in the report of the monitors, as can be seen below.

At the time when I knew that the monitors and the anatomy professors, we would dissect a corpse was quite anxious [...] (Student-monitor 2).

But when the corpse arrived, and I had the first visual contact with it, I had came a certain anguish and had came a series of unpleasant feelings which I can not describe. I fought with myself so that these feelings do not get confused in developing the mini-course dissection, and over time, oddly enough, I began to see the corpse in a different eyes, more professional, leaving the emotional side. I had moments when I forgot that it was a human body and thus could dissect it. Nowadays, I have used it the assistance of the practical lessons of human anatomy [...] (Student-monitor 2). 
The first contact with the corpse was, however, a source of anxiety and curiosity, given the importance [...] (Student-monitor 3).

The first contact with the body is full of curiosity, anxiety and apprehension, since it is a new experience, full of richness teaching and learning experienced by monitors [...] (Student-monitor 4).

In Spain, Arraéz-Aybar, Casado-Morales and Castano-Collado (2004) conducted a study on the level of anxiety during cadaveric dissection classes. With this, have concluded that in the beginning school students had high levels of anxiety and the extent to which the practice became more commonplace, the level of anxiety of these decreased gradually, allowing familiarization with this experience. This emotional variation was observed in the reports presented by the monitors, whereas they never had previous contact with corpses. As the contact was becoming daily, anxiety levels decreased and has not compromised the performance of the monitors in the lab, confirming the authors mentioned above.

\subsection{Teaching-learning process}

Students learn more by using both surface memorization as the deeper understanding and visualization, as could be observed in the Johnson, Charchanti and Troupis (2012) and Pereira, Pleguezuelos, Merí et al. (2007) works. Their studies show that expose students to multiple teaching methods improve their understanding capacity. In the reports exposed by student-monitors could notice the direct influence of cadaveric dissection practice in the teaching-learning process.

The dissection caused me to learn and to understand better how the systems are distributed in the body, something that artificial pieces try to show, but they aren't fully reliable [...] (Student-monitor 1).

[... I could observe how important is the use of the corpse in the practical lessons of human anatomy and neuroanatomy to a better sense of their morphology and actual locations [...] (Student-monitor 2).

The practice of the cadaveric dissection, as a teaching method, it is undoubtedly a factor of addition and better quality of learning supplied by the university [...] (Student-monitor $3)$.

In addition to making the students aware of the reality of anatomy, cadaveric dissection extends the knowledge and provides a new vision of human body [...]. The first contact with the body is full of curiosity, anxiety and apprehension, since it is a new experience, full of richness teaching and learning experienced by monitors [...] (Student-monitor 4).

Costa and Lins (2012) conducted a descriptive study based on survey data from the application of questionnaires with 542 students who attended the course of Human Anatomy in health science courses at the University Federal of Pernambuco of health sciences courses. In this study, when students were questioned if the corpse should only be used in scientific research and not in undergraduate classes, 517 (95.7\%) students have not agreed. When they were asked if the use of corpses could be replaced by computers programs and synthetic materials,
$443(81.9 \%)$ of students responded negatively. And when questioned about substitution by animals, 530 (98.1\%) answered that they aren't in favor.

Additionally, in a study reported that students considered relevant the use of computers, however the practice with dissection is essential; whereas, therefore, the dissection of the main forms of learning (FORNAZIERO and GIL, 2003). Thus, the application of new methodologies such as self-learning modules and software, for example, contribute to the study, but don't replace the body (COLLIPAL and SILVA, 2011).

\subsection{Proximity to veality}

The use of the corpse and dissection provides the nearest model of the future student reality (FORNAZIERO and GIL, 2003). Based on the analysis of the reports, it was revealed the satisfaction of student monitors in handling cadaveric pieces at the expense of artificial parts.

The muscle fascia of cleanliness and separation of the muscles was harder for the delicacy in the process, to separate the muscles one by one and identify them, since the experience I possessed it was just with artificial pieces which are not always faithful to actual position [...] (Student-monitor 1).

[...] given the importance of knowledge to be gained from that experience, since the richness evidenced details on what is real has shown us enough information hidden by artificial anatomical models of laboratory (Student-monitor 3).

However, it is observed that the practical class is an effective way to provide direct contact with the reality (FORNAZIERO, GORDAN, CARVALHO et al., 2010). Students and professionals believe that the human anatomy should be an essentially practical matter, where not only the dissection occupies leading position, but also imaging techniques and solving clinical problems (COLLIPAL and SILVA, 2011).

\subsection{Professor-student interaction}

Experimentation is fundamental in teaching activity what has already been discussed, written and researched (BORGES, 2002), and has shown positive results in a broad way for the teacher-student-monitor (LEITE, SILVA and VAZ, 2005). In this sense, according to the interviewees interaction between teacher-student and student-student are extremely important for their personal and professional experiences.

\section{At the time when I knew that the monitors and the anatomy professors, we would dissect a corpse was quite anxious [...] (Student-monitor 2). \\ [...] to face these situations, we used the casualness monitors between us, during the time that lasted the course (Student- monitor 3 ).}

Insertion of monitors students in practical classes encourages active learning of students by encouraging the construction of knowledge by the students themselves. It is absolutely positive for a student who finds it difficult to learn the material, realize that others one not only learned and passed through it, but also returned, wanting to keep extended contact with discipline, being seen as a model to be followed (REIDENBERG and LAITMAN, 2002). 
Moreover, the experience of using creativity to teach and work with others is a valuable skill to improve the training of communication with the patient. Also team work, decision making and leadership are essential to professionalism, and turn out to improve the interaction with the patient, as well as encourage the formation of a future educator $(\mathrm{KHYCH}$, MARCH, BRYAN et al., 2005).

\subsection{Professional contribution}

Monitoring of Human Anatomy supplies essential assistance for the construction of a qualified professional, since the lack of notions of this discipline, prevents the physiotherapist job in examining, diagnose and treat his patient (ARRUDA and SOUSA, 2014). Thus, it corroborates the reports lectured by student-monitors in this study.

\section{[...] It was an experience which I will carry for the rest of my professional career (Student-monitor 2).}

The practice of the dissection, in the teaching-learning monitors human anatomy is essential for the scientific and professional training of them [...] (Student-monitor 4).

In a study by Reidenberg and Laitman (2002), 89\% of students agreed to be monitor during laboratory dissection has helped to develop their pedagogical skills such as better communication and integration with anatomical terms.

Additionally, for Ramos, Costa, Cascaes et al. (2012) the monitor understands better concepts and correlations, which may be related to the monitor need to acquire better understanding on the professional attitude, demanding leadership attitudes, motivation, interaction and improvisation in eventual situations intervention.

\subsection{Shortage of human corpse to practice dissection}

According to Costa and Lins (2012), even if just for demonstration of anatomical structures, the use of the human corpse is considered as essential for the teaching of human anatomy; and its handling is considered a way to strengthen the humanization of future health professionals. However, the shortage of this teaching resource has been a challenge for higher education institutions (HEI), a fact that corroborates the reported by students in this study.

At the time when we knew, monitors and anatomy teachers, we would dissect a corpse was quite anxious. At last, it was the first corpse of the UPE Petrolina and I was very excited to be able to have this experience [...] (Student-monitor 2).

The first contact with the corpse was, however, a source of anxiety and curiosity, given the importance [...]. (Student-monitor 3)

The first contact with the body is full of curiosity, anxiety and apprehension, since it is a new experience [...]. (Student-monitor 4)

In one study, in which students assumed the role of monitors, $82 \%$ of students agreed that both the understanding and the establishment of the topics studied were higher $(\mathrm{KHYCH}$, MARCH, BRYAN et al., 2005). Thus, the monitor also gets immeasurable gains, since the best way to keep the learning is transmitting it. However, the reduced number of human corpses for teaching purposes has been a constant problem. The provenance of cadaveric material has brought about ethical and legal reflection of the different societies (MELO and PINHEIRO, 2010; JONES and WHITAKER, 2012).

\subsection{Ethical and humanistic approach}

Dissection refers to the technique of opening the human body through cuts, incisions (MOORE, DALLEY and AGUR, 2014). The word derives from Latin in which "dis" means "separate" and "secare" means "cut", etymologically is equivalent to the Anatome, from Greek (GARDNER, GRAY and O'RAHILLI, 1988). In this context, the student-monitors have reported the importance of ethical behavior and humanistic front of dissection act.

[...] I began to see the corpse with more professional eyes (Student-monitor 2).

The course of cadaveric dissection, besides providing a comprehensive of knowledge about human morphology, it has become still somehow, responsible for the humanistic development and improvement of behavioral habits of each student involved, these characteristics required in any professional area health [...] (Student-monitor 3).

In the practice of the dissection, some barriers have been broken,
for example, the question of ethics in using a human body as a
study method [...] It also provided a new vision of both the human
body, asmade us think, too, about our principles and our behavior
in relation to human life [...] (Student-monitor 4 ).

Thus, it is necessary to link the technical aspects of ethical and humanistic for students to develop skills for competence in their professions without forget the humanistic side of the matter (GOMES, REGO, PALÁCIOS et al., 2010).

\section{Conclusion}

The use of human corpses is considered essential to the teaching-learning process in the study of human anatomy, playing a central role in acquiring knowledge and scientific progress. Thus, the dissection of the corpse by the Physiotherapy course monitors students has been seen as a way to strengthen the humanization of future health professionals, reflecting on their ethical-social behavior to adopt an attitude of responsibility and humane with their future patients, well as also contributed to strengthen the teacher-monitor relationship.

Acknowledgements: The authors would like to acknowledge to the Academic Enhancement Program at the University of Pernambuco - PFAUPE for the financial support for the research and researchers dedication and all the staff LABEPAH (Study and Research Laboratory in Human Anatomy).

\section{References}

ARRAEZ-AYBAR, LA., CASADO-MORALES, MI. and CASTANOCOLLADO, G. Anxiety and dissection of the human cadaver: an unsolvable relationship? Anatomical Record B New Anatomist, 2004, vol. 279, n. 1, p. 16-23. http://dx.doi.org/10.1002/ar.b.20022. PMid:15278938.

ARRUDA, RM. and SOUSA, CRA. Aproveitamento teórico-prático da disciplina Anatomia Humana do Curso de Fisioterapia. Revista Brasileira de Educação Médica, 2014, vol. 38, n. 1, p. 65-71. http:// dx.doi.org/10.1590/S0100-55022014000100009.

AVERSI-FERREIRA, TA., NASCIMENTO, GNL., VERA, I., LUCCHESE, R. The practice of dissection as teaching methodology in anatomy applied to medical education. International Journal Morphological, 2010, vol. 28, n. 1, p. 265-272. 
BABINSKI, MA., SGROTT, EA., LUZ, HP., BRASIL, FB., CHAGAS, MA., ABIDU-FIGUEIREDO, M. La relación de los estudiantes con el cadáver en el estudio práctico de anatomía: la reacción e influencia en el aprendizaje. International Journal Morphological, 2003, vol. 21, n. 2, p. 137-142.

BORGES, AT. Novos rumos para o laboratório escolar de ciências. Caderno Brasileiro de Ensino de Física, 2002, vol. 19, n. 3, p. 291-313.

BRASIL. Lei Federal n ${ }^{\circ} 8.501$ de 30 de novembro de 1992. Dispõe sobre a utilização de cadáver não reclamado, para fins de estudo ou pesquisas cientificas e dá outras providências. Diário Oficial [da] República Federativa do Brasil, Brasília, DF, nov. 1992, p. 16519.

BRAZ, PRP. Método didático aplicado ao ensino da anatomia humana. Anuário da produção acadêmica docente, 2009, vol. 3, n. 4, p. 303-10.

COLLIPAL, LE. and SILVA, MH. Estudio de la anatomía en cadáver y modelos anatómicos: impresión de los estudiantes. International Journal Morphological, 2011, vol. 29, n. 4, p. 1181-1185. http:// dx.doi.org/10.4067/S0717-95022011000400018.

COSTA, LF. and FEIJÓS, AGS. Doação de corpos: estudo comparativo luso-brasileiro sobre a utilização do corpo humano para ensino e pesquisa. In Anais do $10^{\circ}$ Salão de Iniciação Científica, 2009. Porto Alegre: X Salão de Iniciação Científica, 2009. 3 p.

COSTA, GBF. and LINS, CCSA. O cadáver no ensino da anatomia humana: uma visão metodológica e bioética. Revista Brasileira de Educação Médica, 2012, vol. 36, n. 3, p. 369-373. http://dx.doi. org/10.1590/S0100-55022012000500011.

DANGELO, JG. and FATTINI, CA. Anatomia humana sistêmica e segmentar. 3. ed. Rio de Janeiro: Atheneu, 2007.

FRANCO, GP. Uma experiência acadêmica como aluno-monitor da disciplina de morfologia: histologia e anatomia. Revista Gaucha de Enfermagem, 1998, vol. 19, n. 1, p. 66-68.

FORNAZIERO, CC. and GIL, CRR. Novas tecnologias aplicadas ao ensino da anatomia humana. Revista Brasileira de Educação Médica, 2003, vol. 27 , n. 2 , p. 141-146.

FORNAZIERO, CC., GORDAN, PA., CARVALHO, MAV., ARAUJO, JC. and AQUINO, JCB. O ensino da anatomia: integração do corpo humano e meio ambiente. Revista Brasileira de Educação Médica, 2010, vol. 34, n. 2, p. 290-297. http://dx.doi.org/10.1590/S010055022010000200014.

GARDNER, E., GRAY, DJ. and O'RAHILLI, R. Anatomia. 4. ed. Rio de Janeiro: Guanabara Koogan, 1988.

GOMES, AP., REGO, S., PALÁCIOS, M. and SIQUEIRA-BATISTA, R. Análise bioética do uso de recém-cadáveres na aprendizagem prática em medicina. Revista da Associação Médica Brasileira, 2010, vol. 56, n. 1, p. 11-16. http://dx.doi.org/10.1590/S0104-42302010000100008. PMid:20339779.

GRAY, HFRS. and GOSS, CM. Anatomia. 29. ed. Rio de Janeiro: Guanabara Koogan, 2012.

JOHNSON, EO., CHARCHANTI, AV. and TROUPIS, TG. Modernization of an anatomy class: from conceptualization to implementation: a case for integrated multimodal: multidisciplinary teaching. Anatomical Sciences Education, 2012, vol. 5, n. 6, p. 354-366. http://dx.doi. org/10.1002/ase.1296. PMid:22730175.

JONES, DG. and WHITAKER, MI. Anatomy's use of unclaimed bodies: reasons against continued dependence on an ethically dubious practice. Clinical Anatomy (New York, N.Y.), 2012, vol. 25, n. 2, p. 246-254. http://dx.doi.org/10.1002/ca.21223. PMid:21800367.

KERBY, J., SHUKUR, ZN. and SHALOUB, J. The relationships between learning outcomes and methods of teaching anatomy as perceived by medical students. Clinical Anatomy (New York, N.Y.), 2011, vol. 24, n. 4, p. 489-497. http://dx.doi.org/10.1002/ca.21059. PMid:20949485.

KRUSE, MHL. Anatomia: a ordem do corpo. Revista Brasileira de Enfermagem, 2004, vol. 57, n. 1, p. 79-84. http://dx.doi.org/10.1590/ S0034-71672004000100017. PMid:15473437.
KRYCH, AJ., MARCH, CN., BRYAN, RE., PEAKE, BJ., PAWLINA, W. and CARMICHAEL, SW. Reciprocal peer teaching: students teaching students in the gross anatomy laboratory. Clinical Anatomy (New York, N.Y.), 2005, vol. 18, n. 4, p. 296-301. http://dx.doi.org/10.1002/ ca.20090. PMid:15832347.

LEITE, ACS., SILVA, PAB. and VAZ, ACR. A importância das aulas práticas para alunos jovens e adultos: uma abordagem investigativa sobre a perspectiva dos alunos do PROEF II. Ensaio Pesquisa em Educação em Ciências, 2005, vol. 7, n. 3, p. 1-16.

MARTYN, H., BARRETT, A., TROTMAN, P. and NICHOLSON, $\mathrm{H}$. Medical students' responses to the dissection of the heart and brain: a dialogue on the seat of the soul. Clinical Anatomy (New York, N.r.), 2012, vol. 25, n. 3, p. 407-413. http://dx.doi.org/10.1002/ ca.21219. PMid:21751255.

MELO, E. and PINHEIRO, J. Procedimentos legais e protocolos para utilização de cadáveres no ensino de anatomia em Pernambuco. Revista Brasileira de Educação Médica, 2010, vol. 34, n. 2, p. 315-323. http:// dx.doi.org/10.1590/S0100-55022010000200018.

MOORE, KL., DALLEY, AF. and AGUR, AMR. Anatomia orientada para a clínica. 7. ed. Rio de Janeiro: Guanabara Koogan, 2014.

NASCIMENTO, FB. and BARLETTA, JB. O olhar do docente sobre a monitoria como instrumento de preparação para a função de professor. Revista Cereus, 2011, n. 5, p. 1-12.

PABST, R. Modern macroscopic anatomy - more than just cadaver dissection. The Anatomical Record, 2002, vol. 269, n. 5, p. 209. http:// dx.doi.org/10.1002/ar.10176. PMid:12379934.

PAIXÃO, ALR., SANTOS, LA. and BARLETTA, JB. Modelagem do manejo de intervenção grupal de monitores de graduação a partir do uso de grupos psicoeducativos. In Anais da $2^{\text {a }}$ Jornada Sergipana de Terapia Cognitiva-Comportamental, 2010. Aracaju: II Jornada Sergipana de Terapia Cognitiva-Comportamental, 2010.

PEREIRA, JA., PLEGUEZUELOS, E., MERÍ, A., MOLINA-ROS, A., MOLINA-TOMÁS, MC. and MASDEU, C. Effectiveness of using blended learning strategies for teaching and learning human anatomy. Medical Education, 2007, vol. 41, n. 2, p. 189-195. http://dx.doi. org/10.1111/j.1365-2929.2006.02672.x. PMid:17269953.

PIAZZA, BL. and CHASSOT, AI. Anatomia Humana, uma disciplina que causa evasão e exclusão: quando a hipótese principal não se confirma. Ciência em Movimento, 2012, vol. 14, n. 28, p. 45-59. http://dx.doi. org/10.15602/1983-9480/cmedh.v14n28p45-59.

RAMOS, LAV., COSTA, DS., CASCAES, JSA., SOUZA, RTS., ROCHA, IFC., GALENO, NS., CARDOSO, MM. Plano de monitoria acadêmica na disciplina de anatomia humana: relato de experiência. Revista Ensino. Saúde e Ambiente, 2012, vol. 5, n. 3, p. 94-101.

REIDENBERG, JS. and LAITMAN, JT. The new face of gross anatomy. Anatomical Record, 2002, vol. 269, n. 38, p. 81-88.

SIQUEIRO NETO, EGB. and FERREIRA, JR. O ensino da anatomia humana no curso de medicina da Universidade Federal de Goiás avaliação e perspectivas. Arquivos de Ciências da Saúde da Unipar, 2001, vol. 5, n. 1, p. 41-50.

TAVANO, PT. Onde a morte se compraz em auxiliar a vida: a trajetória da disciplina de anatomia humana no currículo médico da primeira faculdade oficial de medicina de São Paulo: o período de Renato Locchi (1937-1955). São Paulo: Programa de pós-graduação da Faculdade de Educação, Universidade de São Paulo, 2011. 220 p. [Dissertação de Mestrado em Educação].

TURNEY, BW. Anatomy in a modern medical curriculum. Annals of the Royal College of Surgeons of England, 2007, vol. 89, n. 2, p. 104-107. http://dx.doi.org/10.1308/003588407X168244. PMid:17346399.

Received April 17, 2015 Accepted July 14, 2016 